\title{
Frumkvöðlar og nýsköpun
}

\author{
Rögnvaldur J. Sæmundsson og Örn D. Jónsson ${ }^{1}$
}

\begin{abstract}
Ágrip
Við upphaf 21. aldarinnar var Ísland eitt opnasta pjóðríki í heimi, vel menntuð pjóð með fjölpætt greinabundin tengsl og góðan aðgang að erlendu fjármagni. Tæplega tíu árum síðar hrynur íslenska bankakerfið og fjölmörg stærstu fyrirtæki landsins verða gjaldprota. Í pessari grein eru kenningar Schumpeters, Kirzners og Baumols um frumkvöðulinn og hlutverk hans notaðar til að fjalla um hvernig aukin færni til nýsköpunar, opnun erlendra markaða og einkavæðing leiðir ríka pjóð inn í alpjóðlegt hagkerfi með ófyrirséðum afleiðingum. Spurt er hvort endurskapa megi aftur pær hagfelldu forsendur sem til staðar voru í upphafi aldarinnar og vinna að pví að atvinnulífið leiti í farveg sem er happadrjúgur fyrir íslenskt samfélag. Niðurstaðan er sú að pað sé hægt takist að hlúa að peim sérhæfðu nýsköpunarfyrirtækjum sem haldið hafa velli og byggja upp nýsköpunardrifið hagkerfi. Til pess parf að gera breytingar á stofnanaumhverfi og forðast atvinnustefnu sem byggir á nýtingu fullnýttra náttúruauðlinda.
\end{abstract}

\begin{abstract}
At the beginning of the 21. century the Icelandic economy was characterized by openness, highly educated workforce, diverse international connections, and abundant access to foreign capital. Less than ten years later its banking system has collapsed and many of the country's largest firms are facing bankruptcy. In this paper we use theories of entrepreneurship put forward by Schumpeter, Kirzner and Baumol to analyze how improved innovation capacity, opening of foreign markets, and privatization connects a prosperous micro-state to the international economy with unforeseen consequences. We ask if the favorable conditions at the beginning of the century can be restored and the evolution of the economy directed to a path that is more favorable for the country. We argue that this is possible by attending to the specialized innovation companies that have survived the crisis and focusing on the development of an innovation-driven economy. Changes to the institutional set-up and avoidance of a factor-driven industry policy are pertinent to such development.
\end{abstract}

JEL-flokkun:O1, O3, O25.

Lykilhugtök:Nýsköpun, frumkvöðlastarfsemi, hagpróun, atvinnustefna.

\footnotetext{
${ }^{1}$ Rögnvaldur J. Sæmundsson er dósent við viðskiptadeild Háskólans í Reykjavík og Örn Daniel Jónsson er prófessor við Viðskiptadeild Háskóla Íslands.
} 


\section{Inngangur}

Á 20. öld próaðist Ísland frá pví að vera eitt af fátækustu ríkjum Evrópu yfir í að vera eitt af peim ríkustu sé tekið mið af pjóðartekjum á íbúa (Guðmundur Jónsson 2002). Í kjölfar aðgerða stjórnvalda, uppbyggingar á norrænu velferðarkerfi, gerð fríverslunarsamninga og allvíðtækrar einkavæðingar var hagkerfi landsins við upphaf 21. aldar eitt pað opnasta í heimi, pjóðin vel menntuð, fjölpætt greinabundin fyrirtækjatengsl til staðar og góður aðgangur að erlendu fjármagni. Nokkur fyrirtæki sem byggðu tilvist sína á alpjóðlega samkeppnishæfri nýsköpun, s.s. Marel, Sæplast og Össur, höfðu náð fótfestu á erlendum mörkuðum og pví virtust hafa skapast haldgóðar undirstöður fyrir útrás íslenskra frumkvöðla sem fylgdu í kjölfarið. Tæplega tíu árum síðar hrundi íslenska bankakerfið. Afleiðingarnar fyrir hagsæld pjóðarinnar eru síður en svo að fullu komnar í ljós en áhrifanna mun gæta á næstu árum og jafnvel áratugum.

Umfjöllunarefnið hér er hvernig rík pjóð vex inn í alpjóðlegt hagkerfi með ófyrirséðum afleiðingum. Markmiðið er að leita svara við peirri spurningu hvort og hvernig hægt sé að endurskapa aftur pær forsendur sem voru grunnurinn að víðtækri tengslamyndun íslenskra frumkvöðla og tryggja að hún leiti í farveg sem er happadrjúgur fyrir íslenskt samfélag.

Greinin er byggð upp á eftirfarandi hátt: Fyrst er lauslega farið yfir kenningar priggja fræðimanna um hlutverk frumkvöðulsins og pátt hans í hagpróun og hagsæld. Síðan er fjallað um próun íslensks atvinnulífs og hvernig viðmið og viðhorf frumkvöðlanna breytast í kjölfar einka- og alpjóðavæðingar bankakerfisins. Í kjölfarið er stuttlega fjallað um pær breytingar sem hafa átt sér stað eftir hrun bankakerfisins og leitast við að svara rannsóknarspurningunni.

\section{Fræðileg umræða}

Til að auðvelda umræðuna um próun atvinnulífs undanfarinna tveggja til priggja áratuga má styðjast við kenningar priggja fræðimanna sem fjallað hafa um hlutverk frumkvöðulsins í sögulegu ljósi en peir eru Joseph A. Schumpeter, Israel M. Kirzner og William J. Baumol. Vissulega er um talsverða einföldun að ræða og vísað er til 'frumkvöðulsins' sem hugtaks yfir sérstaka starfshætti sem gegna hlutverki í efnahagslífinu fremur en til ákveðinna einstaklinga og pátt peirra í hinni eiginlegu atburðarás nýsköpunar og pjóðfélagsbreytinga. ${ }^{2}$ Á sama hátt verður að hafa í huga regluverkið og stofnanaumhverfið sem frumkvöðlar starfa í og aðrar aðstæður sem bæði skapa og takmarka möguleika peirra athafna.

Í kenningum Schumpeters $(1934,1942)$ hefur frumkvöðullinn pað hlutverk að vera nýskapandi hreyfiafl atvinnulífsins. Nýsköpun frumkvöðulsins felst í notkun nýrra framleiðslupátta, nýjum samsetningum peirra, breyttu skipulagi eða opnun nýrra markaða. Hún brýtur upp pað jafnvægi sem ríkir í atvinnulífinu og verður forsenda fyrir aukinni verðmætasköpun og hagnaði. Hún er öflugt vopn í samkeppni par sem ráðist er að tilverugrundvelli starfandi fyrirtækja, t.d. með notkun á nýrri tækni sem gerir eldri tækni úrelta. Í fótspor frumkvöðla feta eftirhermur (e. imitators) sem betrumbæta nýsköpun frumkvöðlanna og auka útbreiðslu hennar. Að lokum geta ráðandi fyrirtæki og jafnvel

2 Í pessum skilningi er ekki gerður greinarmunur á frumkvöðlastarfi sem felur í sér stofnun nýrra fyrirtækja, frumkvöðlastarfsemi á vegum starfandi fyrirtækja eða frumkvöðlastarfi einstaklinga og hópa. 
atvinnugreinar ekki varist samkeppninni og í kjölfarið rísa og hníga atvinnugreinar; ferli sem Schumpeter (1942) kallar 'skapandi eyðileggingu' (e. creative destruction). Jafnvel pó að skammtímaáhrifin geti verið erfið fyrir pá sem verða undir í samkeppni eru heildaráhrifin jákvæð fyrir efnahagslífið og nauðsynleg forsenda aukinnar hagsældar. ${ }^{3}$

คó að frumkvöðlar gegni hlutverki 'gerandans' nær nýsköpunarhugtakið allt eins til starfsskilyrða peirra. Nýsköpun er gildisbundið ferli, takmarkað af ákveðnu regluverki og sögulegum aðstæðum sem afmarka hvað er hagnýtt og hvað ekki (Nelson 1992). Ferlið felur í sér mismarkvissa sköpun nýjunga og tilraunir til hagnýtingar peirra og ekki er hægt að gera ráð fyrir að um sé að ræða einfalda hagnýtingu vísindapekkingar (Kline and Rosenberg 1986). Nýnæmi ræðst af aðstæðum hverju sinni, í sumum tilfellum er um að ræða staðbundið nýnæmi (nýtt undir paki), í öðrum tilfellum alpjóðlegt (nýtt undir sólu) (Freeman 1982). Vegna óvissu um útkomu er aðgangur að lánsfjármagni nauðsynleg forsenda nýsköpunar, sérstaklega ef nýnæmi er mikið. Slíkt lánsfjármagn er varla aðgengilegt nema fjármagnseigendur séu tilbúnir að taka pá áhættu sem í óvissunni felst. Við stórar tæknibreytingar sem fela í sér skapandi eyðileggingu, t.d. innleiðingu gufuvélarinnar, járnbrautanna og tölvutækninnar, myndast gjarnan væntingar um breyttar aðstæður og mikla hagnaðarvon. Eftirhermur rjúka pá gjarnan til að nýta sér pessi tækifæri með aðstoð fjármagnseigenda. Aukið fjármagn í umferð og væntingar um framtíðarhagnað leiða til eignaverðbólgu sem framtíðarhagnaður nær ekki að standa undir. Við pað myndast bóluhagkerfi, byggt á væntingum sem ekki er hægt að uppfylla í raunhagkerfinu og parf að leiðrétta fyrr eða síðar (Perez 2002).

Kirzner $(1973,1997)$ ætlar frumkvöðlinum ólíkt hlutverk pótt athafnir hans séu einnig mikilvægar fyrir próun atvinnulífsins og hagsæld samfélagsins. Samkvæmt Kirzner er frumkvöðullinn árvakur (e. alert) einstaklingur sem sér og er tilbúinn að nýta pau tækifæri sem felast í ójafnvægi efnahagslífsins en af margvíslegum ástæðum, t.d. ólíkri pekkingu pátttakenda og mismunandi aðgangi að upplýsingum, leitar efnahagslífið stöðugt út úr jafnvægi sínu. Ójafnvægið leiðir til pess að framleiðslupættir eru ekki verðlagðir í samræmi við verðmæti peirra og í pví felast tækifæri til hagnaðar fyrir frumkvöðulinn. Með starfsemi sinni upplýsir frumkvöðullinn hins vegar um verðmæti framleiðslupáttanna. Við pað leitar efnahagslífið jafnvægis sem stuðlar að betri nýtingu framleiðslupátta og aukinni velferð. Greining Kirzners samræmist að vissu marki hugmyndum Schumpeters um hlutverk eftirherma en horfir framhjá pví vægi sem Schumpeter eignar róttækum tækninýjungum og pætti fjármagnseigenda. Schumpeter leggur áherslu á pátt frumkvöðla í að skapa misvægi en Kirzner á pátt peirra í að koma á jafnvægi.

Samkvæmt kenningum Baumols (1993) sinnir frumkvöðullinn bæði hlutverki nýskapandi upphafsmanns sem stendur fyrir breytingum í atvinnulífinu og pess sem nýtir sér breytingarnar í hagnaðarskyni, eykur par með útbreiðslu peirra og stuðlar að jafnvægi í hagkerfinu. Мeð pví sameinar hann að einhverju leyti sjónarmið Schumpeters og Kirzners um áhrif frumkvöðulsins á skipulag og nýtingu framleiðslupátta í efnahagslífinu en ólíkt

\footnotetext{
${ }^{3}$ Hugmyndir Schumpeters um skapandi eyðileggingu áttu við umfangsmiklar tæknibreytingar, s.s. gufuvélina, járnbrautir og rafmagn. Pví má halda fram að hugtakið sé gjarnan misnotað um atburði sem hafa ekki eins umfangsmikil áhrif á samfélagið. Eigi að síður felst grunnhugmynd Schumpeters í pví að samkeppni milli fyrirtækja byggist ekki eingögnu á verði og kostnaði fyrir sambærilegar vörur heldur einnig á nýsköpun sem ekki er hægt að mæta með breytingum á verði og kostnaði á eldri vörum. Ef fyrirtæki eða atvinnugreinar eru ófær um að mæta slíkri samkeppni má segja að pau verði fórnarlömb nýrrar sköpunar.
} 
peim fyrrnefndu gerir hann ekki ráð fyrir að áhrif frumkvöðulsins á hagsæld séu alltaf jákvæð pegar á heildina sé litið. Samkvæmt Baumol (1993) ræðst farvegur peirrar frumkvöðlastarfsemi sem á sér stað á hverjum tíma af pví hvernig hagrænir hvatar eru upp byggðir (e. structure of payoffs). Í besta falli leiða hagrænir hvatar til nýsköpunar og aukinnar hagsældar en í sumum tilfellum getur uppbygging peirra gefið af sér frumkvöðlastarfsemi sem er ekki til pess fallinn að auka hagsæld samfélagsins og getur jafnvel dregið úr henni. Sem dæmi um slíka starfsemi nefnir hann rentusókn (e. rent seeking) par sem frumkvöðullinn leitast við að skara eld að eigin köku án pess að samsvarandi ávinningur skili sér til efnahagslífsins. Hér er ekki átt við ólöglega starfsemi sem vinnur í eðli sínu gegn hagsæld samfélagsins, t.d. sölu á eiturlyfjum eða fjárkúgun, heldur starfsemi sem rúmast innan laga og reglna samfélagins, svo sem pegar hluthafi sem hótar yfirtöku er keyptur út á yfirverði eða pegar öflugir fjárfestingasjóðir hreyfa við mörkuðum. Stjórnvöld hafa bæði bein og óbein áhrif á uppbyggingu hagrænna hvata, t.d. með löggjöf, stefnumörkun og aðgerðum, en peir ráðast líka af peirri menningu sem ríkir í atvinnulífinu hverju sinni.

Hugmyndir Baumols má túlka á pann veg að hagrænir hvatar hafi áhrif á pað hvort sú ofjárfesting sem gjarnan fylgir í kjölfar róttækrar nýsköpunar hafi jákvæð eða neikvæð áhrif á hagsæld pjóða. Pó svo að offjárfesting í kjölfar róttækrar tækninýsköpunar skili ekki hagnaði til peirra frumkvöðla og fjármagnseigenda sem stóðu fyrir henni pá hagnast samfélagið af peim tækifærum sem hún skapar, t.d. með aukinni tæknipekkingu og greinabundnum tengslum fyrir pá sem á eftir koma. Ólíklegt er að pað sama eigi við um róttækar nýjungar til rentusóknar, bæði vegna pess að frekari rentusókn leiðir ekki til hagsældar og að líklegt er að leitast sé við að koma í veg fyrir slíka rentusókn í framtíðinni.

Tækifæri og aðstæður til frumkvöðlastarfs tengjast próunarstigi hagkerfa (GEM 2010). Próaðari hagkerfi styðja betur við starfsemi frumkvöðla en pau sem styttra eru á veg komin, með sterkari sérpekkingu, aukinni sérhæfingu og aðgangi að stærri pátta- og vörumörkuðum. Ein leið til að leggja mat á próun hagkerfa er greining Porters (1998) á peim drifkröftum alpjóðlegrar samkeppnishæfni sem eru ríkjandi á hverjum tíma. Porter greinir á milli fjögurra mismunandi próunarstiga:

- Auðlindadrifið: Samkeppnisstaða byggist að mestum hluta á peim auðlindum sem eru til staðar, svo sem náttúruauðlindum og vinnuafli. Vörur til útflutnings eru einsleitar og framleiðni lítil sem birtist í lágum launum.

- Fjárfestingadrifið: Samkeppnisstaða byggist á fjárfestingum í skilvirkari framleiðsluferlum og betri gæðum vöru og pjónustu. Tækniyfirfærsla á sér stað, sérfræðipekking eykst og aðgreining verður meiri á alpjóðlegum mörkuðum.

- Nýsköpunardrifið: Samkeppnisstaða byggist á alpjóðlega samkeppnishæfri nýsköpun, p.e. röð nýrra og endurbættra vara og pjónustu sem byggja á próuðum og sérhæfðum framleiðsluferlum. Færni til nýsköpunar byggist á öflugri grunngerð, p.m.t. vel menntuðu vinnuafli, tengslum við kröfuharða viðskiptavini, heilbrigðri samkeppni innanlands og samspili tengdra atvinnugreina (klasa).

- Auðsdrifið: Samkeppnisstaða byggist á pví að tryggja og viðhalda peim auði sem myndast hefur og dreifa honum um samfélagið. Nýsköpun minnkar, fjárfestingar í sérhæfðum atvinnugreinum dragast saman og minni hvatar eru til frumkvæðis einstaklinga. Hættan á stöðnun og jafnvel samdrætti eykst. 
Samkvæmt Porter (1990) eykst auðlegð pjóða sem og almenn lífskjör borgaranna eftir pví sem pjóðirnar færast á hærra próunarstig. Próunin er stígbundin, takmörkuð af stofnanaumhverfi og sögulegum aðstæðum. Frumkvöðlar gegna mikilvægu hlutverki við nýsköpun og útbreiðslu hennar á fyrstu premur stigunum. Á fyrstu tveimur er nýsköpunin staðbundin, p.e. hún byggist fyrst og fremst á pví að kynna til sögunnar og aðlaga vörur, pjónustu og verklag sem er vel pekkt annars staðar. Á priðja stiginu verður hún alpjóðleg.

Í næsta kafla munum við skoða próun íslensks atvinnulífs frá pví um miðja síðustu öld í ljósi kenninga Schumpeters, Kirzners og Baumols um hlutverk frumkvöðulsins og í samhengi við hugmyndir Porters um próunarstig hagkerfa.

\section{Próun atvinnulífs á Íslandi frá miðri 20. öld}

Á 20. öld próaðist íslenskt samfélag úr pví að vera nýlenda og eitt fátækasta samfélag Evrópu í að vera ein efnaðasta pjóð heims við aldarlok ef mið er tekið af pjóðartekjum á einstakling (Guðmundur Jónsson 2002). Eins og rakið er hjá Erni D. Jónssyni og Rögnvaldi J. Sæmundssyni (2006) átti próunin sér stað yfir nokkur tímabil frumkvæðis og uppbyggingar par sem stjórnvöld voru annað hvort virkir pátttakendur eða stefna peirra leysti úr læðingi öfl innan samfélagsins, oftar en ekki með ófyrirsjáanlegum afleiðingum. Sé dregin upp mynd af íslenska nýsköpunarkerfinu (Lundvall 1991) með breiðum pensilförum má sjá nokkuð augljós einkenni. Sveigjanleikinn var nánast einstakur. Launafólk var tilbúið að taka á sig launalækkun og bæta upp fyrir hana með lengri vinnudegi. ${ }^{4}$ Pegar vel gekk í einstökum greinum, oftar en ekki á kostnað annarra, var pað látið viðgangast; uppsveifla í sjávarútvegi gat dregið úr samkeppnishæfni annars útflutningsiðnaðar, uppbygging bankakerfisins dró til sín tæknimenntað fólk, pensla vegna stóriðjuframkvæmda var að vissu marki á kostnað útflutingsgreina vegna styrkingar krónunnar. Á stuttum tíma opnaðist kerfið upp á gátt með breyttu regluverki og myndun víðtækra alpjóðlegra tengsla og nýsköpun á mörgum sviðum varð alpjóðleg.

Í byrjun sjötta áratugarins var stefnt að pví að byggja upp blandað hagkerfi að skandínavískri fyrirmynd og efla grunnviði og stofnanir sem taldar voru nauðsynlegar forsendur farsæls velferðarsamfélags. Nýsköpun í nútímaskilningi var nánast ekki til; hún var fremur skilgreind sem pólitísk átaksverkefni par sem áherslan var á að taka upp nýjungar að erlendri fyrirmynd. Svigrúm framkvæmdamanna með hugvitssamlegar lausnir var takmarkað og fjármagn til fjárfestinga í nýsköpun naumt skammtað. ${ }^{5}$ Frumkvöðlar voru 'athafnaskáld' eða 'berserkir', allt eftir pví hver lýsti störfum peirra. ${ }^{6}$ Eitt einkenni tímabilsins var að verkefni til uppbyggingar voru ærin og auðsýnileg. Spurningin var um forgangsröðun, hver ætti að framkvæma og hvort sá hinn sami hefði bolmagn til pess. Nýsköpun tímabilsins fólst í pví að leggja grunninn að velferðapjóðfélagi með blönduðu hagkerfi par sem áhersla var lögð á fjárfestingar í grunngerð og skilvirkari framleiðsluferlum í sjávarútvegi. Stjórnvöld höfðu haft hlutverk hins nýskapandi frumkvöðuls með fjárfestingum sínum, byggðum á uppsöfnuðum sparnaði stríðsáranna og próunaraðstoð vin-

${ }^{4}$ Fyrstu viðbrögð við upphaf núverandi samdráttar var almenn launalækkun gegn ákveðnum skilyrðum/sáttmála.

${ }^{5}$ Hér er oft vísað til skuttogara, kraftblokkar og fiskileitartækja, en hugmyndirnar voru sannanlega próaðar fyrst hér en útfærðar erlendis.

${ }^{6}$ Orðið athafnaskáld er komið frá Matthíasi Johannesen á meðan Halldór Kiljan Laxness gerir góðlátlega grín að frumkvöðlinum sem óhefluðum göslara sbr. Íslands-Bersai í Guðsgjafapulu. 
veittra bandamanna. Hagkerfið var pví að taka sín fyrstu skref úr pví að vera auðlindadrifið í pað að vera fjárfestingadrifið.

Í upphafi áttunda áratugsins komu fram frumkvöðlar, tengdir sjávarútvegi, sem sáu tækifæri í að hagnýta pá öru tæknipróun sem tengdist tilkomu örgjörvans og aukinni pekkingu í efnistækni. Peir voru nýskapandi í skilningi Schumpeters (1934) á pann hátt að peir próuðu nýjar úrlausnir sem losuðu um pá flöskuhálsa sem höfðu hægt á verðmætasköpun innan greinarinnar (Dahmén 2004). Samfara öðrum breytingum, m.a. innleiðingu nýs fiskveiðstjórnunarkerfis, sköpuðu peir grundvöll að umbyltingu atvinnugreinarinnar með breyttu verklagi og tilheyrandi breytingum á valdahlutföllum innan hennar.

Hér voru fjórir pættir mikilvægastir: Aukið nýtingarhlutfall, varðveisla ferskleika fisksins, aukin verðmæti með vörupróun og aukin sérhæfing í kjölfar nánari tengsla við viðskiptavini (Örn D. Jónsson 2000). Almennt má segja að viðfang allra pessara fjögurra pátta hafi að uppistöðu til verið verkfræðilegs eðlis en pó að hluta pverfaglegt og krafðist pekkingar sem var sértæk og almenn í senn. Sem dæmi má nefna að sjóvogin, sem leggur grunninn að uppbyggingu Marels, byggði á ákveðinni reiknitækni við vigtun við sérstakar aðstæður, rafsuðu á ryðfríu stáli með nákvæmnistigi sem var aðeins á færi örfárra sem og vatnsheldni við erfiðar aðstæður. Fiskikassar Sæplasts, sem einfölduðu mjög alla meðhöndlun á fersku hráefni, byggðu á úrepanfyllingu með blöndu af form- og prýstisteypu. Bakkavör gerði tilraunir til að auka verðmæti hrogna, sem voru í mjög takmörkuðu magni, með pví að búa til ídýfur og og stórauka pannig sölumagnið (Taramasalata).

Fljótlega kom í ljós að pær lausnir sem próaðar voru sem nýsköpun í fiskvinnslu áttu einnig erindi við aðra matvælavinnslu og aðra markaði en pann íslenska. Pannig var framleiðslukerfi fisksins haldgott í kjúklingaframleiðslu, einangruð ker Sæplasts gagnleg í heitum löndum og færni frumkvöðlanna í Bakkavör við gerð tilbúinna rétta skóp, með öflugu baklandi innlendra fjárfesta, tækifæri til að svara vaxandi pörf fyrir pægindafæði í Bretlandi.

Ólíkt pví sem áđur var hafði uppbygging í íslensku atvinnulífi byggst á nýsköpun sem var ný undir sólinni og eftirspurn var eftir pessari nýsköpun erlendis. Samhliða frumkvöðlum í sjávarútvegi fór að bera á svipuðum sprotum í öðrum atvinnugreinum, sbr. fyrirtækið Össur sem nýtti sér nýjungar í efnistækni til próunar stoðtækja en Össur var með einkaleyfi á sílikonhulsu.

Prátt fyrir pátttöku í EFTA fríverslunarbandalaginu (1970) ríkti ekki pað frjálsræði í fyrirkomulagi utanríkisverslunar sem var nauðsynleg forsenda útrásar íslenskra frumkvöðla. Par hafa líklega tvö atriði skipt meginmáli:

- Útflutningur sjávarfangs, sem var um 90\% heildarútflutnings, var að uppistöðu til í höndum fjögurra til fimm aðila eða fámenns hóps á vegum sölusamtaka, m.ö.o. kartelfyrirkomulag. Kaupgeta í fiskmenningarlöndum í Asíu og við Miðjarðarhafið jókst og peir sem höfðu innsýn til að pjónusta pá markaði högnuðust vel. Forsvarsaðilum hlutaðeigandi atvinnugreina var mikið í mun að koma í veg fyrir að 'utanaðkomandi’ öðluðust færni á sviði útflutnings.

- Sérpekking, færni og tengslanet færist ekki auðveldlega á milli einstakra atvinnugreina. Erfitt er að brjóta sér leið inn í hóp innvígðra sem hafa á að skipa dulinni pekkingu (e. tacit knowledge), verkfærni og tengslum innan einstakra atvinnugreina og markaða, jafnvel pó að innan hópsins ríki hörð samkeppni. Рað var pví erfitt að nýta tengsl og 


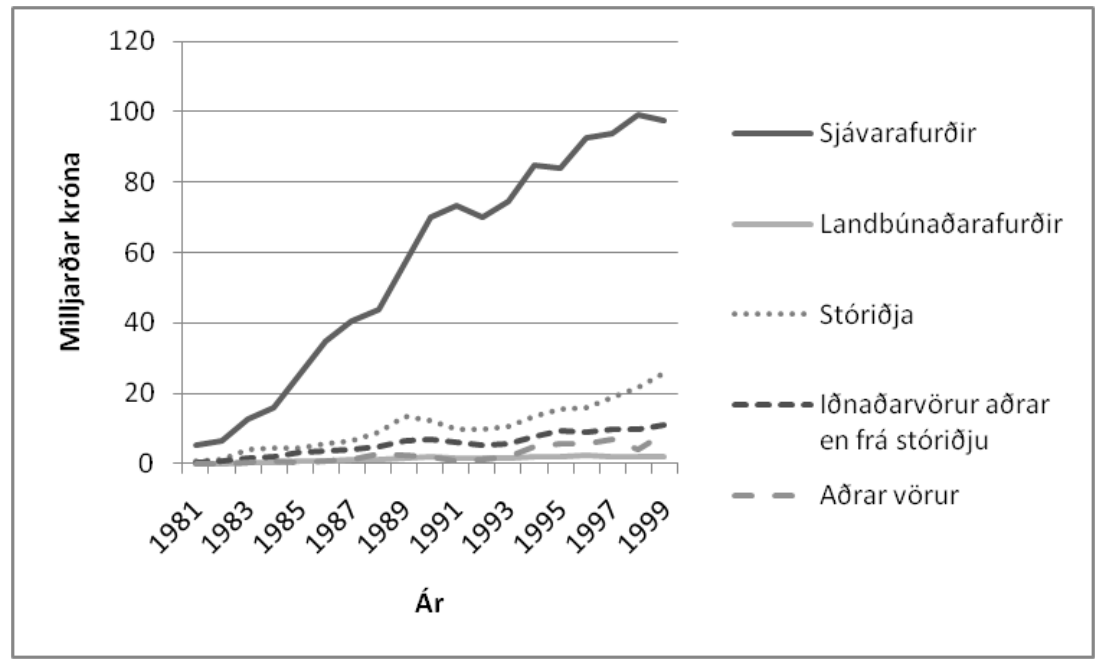

Mynd 1. Vöruútflutningur á Íslandi 1981-2000

Heimild: Hagstofa Íslands.

pekkingu innan fiskvinnslunnar til pess að sækja inn í nýjar atvinnugreinar, jafnvel á tengdum sviðum. ${ }^{7}$

Umbóta var pörf og almenn samstaða var um að bæta starfsskilyrði atvinnulífsins og færa í frjálsræðisátt, pá sérstaklega að koma á virkum hlutafjármarkaði og raungera með aðstoð hans fjölbreytni á sviði útflutnings.

Tilraunir höfðu verið gerðar til að stofna til opinbers markaðar með hlutabréf á Íslandi en segja má að slíkur markaður hafi ekki fest sig í sessi fyrr en árið 1990 pegar fyrstu hlutabréfin voru skráð á Verðbréfapingi. Íslenskur hlutabréfamarkaður óx hægt í byrjun og voru sjávarútvegsfyrirtæki og fyrirtæki tengd peirri grein fyrirferðamikil fyrstu árin. Fljótlega starfaði priðjungur fyrirtækja við útgerð og vinnslu og árið 1997 náði hlutfallslegt virði peirra hámarki við 40\% (Erla Kristinsdóttir 2009). Pessum fyrirtækjum, sem áður öfluðu fjármagns með aðstoð pólitískra tengsla innan bankakerfisins, var nú gert kleift að nýta sér kosti markaðsfyrirkomulagsins til eflingar. Nýsköpunarfyrirtæki tengd sjávarútvegi náðu einnig að fjármagna vöxt sinn með sókn á erlenda markaði og inn í aðrar atvinnugreinar, t.d. kjötvinnslu. Skortur á hráefni takmarkaði hins vegar vöxt iðnfyrirtækja sem tengdust landbúnaði.

Prátt fyrir tilkomu hlutafjármarkaðar, lækkun tolla og opnun erlendra markaða með aðild að EES (1993) og GATT (1995) höfðu pessir pættir pegar á heildina er litið ekki mikil áhrif á fjölbreytni í útflutningi, a.m.k. fyrst um sinn (mynd 1). Vöruútflutningur jókst pó jafnt og pétt á níunda áratugnum í kjölfar framfara í sjávarútvegi.

Pegar rýnt er nánar í tölurnar má pó sjá að útflutningur hátæknivara tók mikinn kipp á tímabilinu 1990-1995 (Rannsóknarráð Íslands 1996). Til dæmis tæplega tvöfaldaðist útflutningur á fiskvinnsluvélum og rafeindavogum, úr 700 milljónum árið 1990 í 1.300 milljónir árið 1995, sala á hugbúnaði fór úr nánast engu upp í 800 milljónir, sala lyfja úr minna en 50 milljónum í 600 milljónir og sala stoðtækja úr minna en 25 milljónum í rúmlega

${ }_{7}$ Markaður fyrir frystan fisk var hráefnistengdur - frystihirslur stórmarkaðanna voru einokaðar af örfáum stórfyrirtækjum eins og Unilever. Í Bandaríkjunum var megináherslan á stórkaup stofnana og veitingakeðja. Í báðum tilfellum án auðkennis um uppruna vörunnar eða annarrar aðgreiningar. 
250 milljónir. Nýir möguleikar höfðu skapast samhliða aukinni færni til nýsköpunar, uppbygginu hlutabréfamarkaðar og auknu frjálsræði í alpjóðviðskiptum. Árvakrir frumkvöðlar (Kirzner 1997) höfðu komið fram til að nýta pessi tækifæri til útrásar.8 Nýsköpun var orðin alpjóðleg og prátt fyrir að verðmætasköpun og samkeppnishæfni væri ennpá drifin áfram af framförum í sjávarútvegi sköpuðu pær framfarir ekki einungis nýja og skilvirkari vinnslumöguleika heldur einnig sölu á nýjum framleiðslutækjum sem hafði margfalt meiri vaxtarmögleika en áframvinnsla á fiski í landi. Рað var pví kominn vísir að pví að hagkerfið gæti færst yfir á næsta stig próunar og orðið nýsköpunardrifið.

Með einkavæðingu bankakerfisins sköpuðust enn fleiri tækifæri fyrir íslenska frumkvöðla. Aðgangur að innlendu og síðar erlendu fjármagni batnaði og fjárfestingageta atvinnulífsins margfaldaðist. Einkavæðingin hófst með sölu Útvegsbankans árið 1998 og lauk pegar Búnaðarbankinn hvarf að fullu úr eigu ríkisins árið 2003. Í kjölfar einkavæðingarinnar stóðu prír bankar eftir, Íslandsbanki, KB banki og Landsbankinn, sem stækkuðu mjög hratt með aukinni starfsemi erlendis.

Útpensla og stærð bankana hafði mikil áhrif á íslenskt atvinnulíf. Við skoðun á fyrirtækjum sem skráð voru í Kauphöll Íslands árið 2006 (mynd 2) sést að markaðsvirði peirra hafði margfaldast og bankar og fjármálastofnanir voru orðnar fyrirferðamestu fyrirtækin á markaðnum, ásamt fyrirtækjum sem tengdust að uppistöðu til fáeinum viðskiptablokkum í kringum bankana. Æ fleiri fyrirtæki voru orðin að fjárfestingarfyrirtækjum jafnvel pótt pau héldu nöfnum gömlu fyrirtækjanna. Til dæmis höfðu bæði Flugleiðir og Eimskip í raun breyst í vogunarsjóði. Flest vinnslufyrirtæki í sjávarútvegi voru dottin út af markaðnum og fá fyrirtæki sem stunduðu alpjóðlega nýsköpun höfðu bæst við. Skráður hagnaður bankanna var orðinn margfalt virði pess sem fékkst fyrir útfluttar sjávarafurðir.

\section{6}

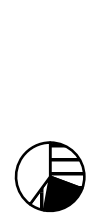

93.099.755.203 kr.

Mynd 2. Samanburður á markaðsvirði hlutabréfa í Kauphöll Íslands 1996 og 2006 Heimild: Kauphöll Íslands.

8 Einnig skiptir hér miklu máli uppbygging menntakerfisins og efling alpjóðlegrar pekkingar og tengsla í kjölfar pess að fleiri sækja sér framhaldsnám erlendis og vinna par að loknu námi (sjá nánar í Örn D. Jónsson og Rögnvaldur J. Sæmundsson 2006). 
Í stað pess að styrkja pann vísi sem kominn var að nýsköpunardrifnu hagkerfi hafði einkavæðing og útrás bankanna pveröfug áhrif til veikingar. Auknir möguleikar til fjárfestinga nýttust ekki nema að takmörkuðu leyti til styrkingar á peim atvinnugreinum sem fyrir voru, t.d. í sjávarútvegi, og að mjög litlu leyti til alpjóðlegrar nýsköpunar í skilningi peirra Schumpeters og Kirzners. Í staðinn sköpuðust aðstæður og sterkir hvatar til rentusóknar og eignaverðbólgu (Páll Hreinsson, Sigríður Benediksdóttir og Tryggvi Gunnarsson 2010). Útrásin og hröð stækkun bankanna gerði pað að verkum að rentusóknin varð fljótlega af alpjóðlegri stærðargráðu og tók mið af venjum í City í London frekar en Reykjavík, p.e. stærð og gerð viðskiptasamninga var í litlu samræmi við venjur í íslensku atvinnulífi eða stærð íslenska raunhagkerfisins sem stóð að baki lánshæfismati íslensku bankanna. Prátt fyrir róttæka nýsköpun í vissum skilningi urðu hinir nýskapandi frumkvöðlar pað eyðileggingarafl sem Baumol varar við og stærðarhlutföllin nánast einstök. ${ }^{9}$

Spurningin hér er hversu mikil áhrif pessi darraðadans hefur haft á íslenska raunhagkerfið og pann vísi að nýsköpunardrifnu hagkerfi sem hafði myndast í kringum aldamótin. Við snögga skoðum má sjá að á síðustu tveimur áratugum hafa próast hér allmörg pekkingarfyrirtæki sem hafa vaxið innan sérhæfðra markaða á alpjóðavettvangi (sjá mynd 3). Pessi fyrirtæki voru ósýnileg pegar öll athyglin beindist að uppgangi fjármálakerfisins og stórtækra fjárfestinga á alpjóðamarkaði. Pau hafa tekjur sínar erlendis frá og eru pví líkleg til að hafa víðtæka möguleika til vaxtar prátt fyrir breytt starfsskilyrði. Í næsta kafla verður fjallað um breytingar á starfsskilyrðum pessara fyrirtækja og hvort og hvernig hægt er að endurskapa pær hagfelldu aðstæður sem voru til staðar rétt fyrir aldamótin par sem vísir var kominn að nýsköpunardrifnu hagkerfi.

\section{$4 \quad$ Breytingar í kjölfar hrunsins}

Frá hruni bankakerfisins haustið 2008 hefur verið unnið að pví að endurheimta raunhagkerfið úr rústum bóluhagkerfisins. Stærsta verkefnið er að endurreisa fjármálakerfi pjóðarinnar en einnig parf að takast á við samdrátt í efnahagslífinu og háa skuldastöðu fyrirtækja og einstaklinga. Hér verður ekki fjallað á tæmandi hátt um breytingar sem snúa að lausn pessara verkefna heldur sérstaklega fjallað um atriði sem snúa að uppbyggingu nýsköpunardrifins hagkerfis og atvinnustefnu stjórnvalda.

Litlar breytingar virðast hafa orðið á atvinnustefnu stjórnvalda. Í stefnuyfirlýsingu núverandi ríkisstjórnar er lögð áhersla á „fjölbreytt atvinnulíf, jafnan en stöðugan hagvöxt, nýsköpun og sjálfbæra nýtingu til lands og sjávar" (Forsætisráðuneytið 2010, bls. 8) en fjölbreytt atvinnulíf og áhersla á nýsköpun hefur verið á stefnuskrá flestra ríkisstjórna síðustu árin. Úr pessu má lesa að stjórnvöld stefni að pví að íslenska hagkerfið verði nýsköpunardrifið.

Prátt fyrir pessa stefnu er talsverður prýstingur á stjórnvöld að beita sér fyrir úrræðum sem hvetja til meiri auðlindanýtingar og fjárfestinga í öflugri og skilvirkari grunngerð. Sem

9 Prátt fyrir hugmyndir um að íslenskir kaupsýslumenn hafi innleitt nýja aðferðafræði við fjárfestingar og fyrirtækjarekstur (sjá t.d. Helga Harðardóttir og Snjólfur Ólafsson 2007) er vafasamt að tala um alpjóðlega nýsköpun á pví sviði. Útrás íslenskra kaupsýslumanna á sér stað á sama tíma og stóraukið framboð er á lánsfé um allan heim og ákvarðanir um skuldsettar yfirtökur byggjast á væntingum um hækkun eignaverðs og takmarkalausan aðgang að lánsfé á hagstæðum kjörum. Hins vegar er óumdeilanlegt að róttækar breytingar áttu sér stað á Íslandi. 
dæmi má nefna kröfur um auknar aflaheimildir, strandveiðar, áherslur ákveðinna sveitarfélaga á raforkuframleiðslu og uppbyggingu stóriðju, tvöföldun fjölfarinna vega, byggingu hátæknisjúkrahúss, byggingu tónlistarhúss og fjárfestingar í ferðapjónustu. Margar af pessum aðgerðum eru skiljanlegar skammtímalausnir til að bregðast við atvinnuleysi, sporna gegn flótta af landsbyggðinni eða auka erlendar fjárfestingar til að styrkja gengi krónunnar og auka trúverðugleika á erlendum fjármálamörkuðum. Arðsemi peirra er hins vegar takmörkuð og pær styðja ekki markvisst við uppbyggingu nýsköpunarhagkerfis.

Sjávarútvegur, orkuvinnsla og á vissan hátt ferðapjónustan líka eru allt dæmi um atvinnugreinar sem nýta takmarkaðar náttúruauðlindir til verðmætasköpunar. Auðvelt er að ganga of mikið á höfuðstólinn sem dregur úr möguleikum til verðmætasköpunar í framtíðinni. Í sjávarútvegi er ferskleiki fisksins lykilatriði og forsenda aðgreiningar á erlendum mörkuðum pannig að frekari áframvinnsla innanlands gefur mjög takmarkaða möguleika til aukinnar verðmætasköpunar. Aflamark er nálægt fullnýtingu og aukning aflaheimilda tæplega sjálfbær. Í orkuvinnslunni hefur hagkvæmum kostum til orkuvinnslu fækkað mjög á síðustu árum miðað við núverandi tæknistig og pess vegna eru tæknibreytingar forsenda áframhaldandi uppbyggingar. Í ferðapjónustu hefur aukning ferðamanna aukið ágang á vinsælum svæðum auk pess sem ferðapjónustan keppir við orkuiðnaðinn um náttúruauðlindir en margir af vinsælustu áfangastöðum ferðamanna eru nálægt háhitasvæðum.

Pó svo að framkvæmdir við hátæknisjúkrahús, tónlistarhús og tvöföldun vega séu allt verðug verkefni verður ekki horft framhjá pví að pær skapa ekki róttæka viðbót við pá grunngerð sem til staðar er. Byggingaframkvæmdir sem einungis hafa að markmiði að halda uppi atvinnustigi meðan á framkvæmdum stendur en bæta litlu við pá grunngerð eða framleiðslukerfi sem fyrir er eru ólíklegar til pess að vera arðsamar til lengri tíma, sérstaklega pegar litið er til peirra aðstæðna sem ríkja í dag. Fjármagnskostnaður er hár og skortur á fjármagni til framkvæmda leiðir til hás fórnarkostnaðar.

Um leið og arðsemi framkvæmdanna sjálfra er takmörkuð til lengri tíma er sýnu alvarlegra að pær styðja ekki nema að takmörkuðu leyti við uppbyggingu nýsköpunardrifins hagkerfis. Eins og kom fram í fræðilega hluta greinarinnar er nýsköpun stígbundið ferli par sem sögulegar aðstæður hafa áhrif á uppbyggingu, færni og aðstæður til verðmætasköpunar. Auk pess hefur sagan sýnt að í litlu hagkerfi eins og pví íslenska er áhersla á einstakar atvinnugreinar gjarnan á kostnað annarra. Að pessu sinni er líklegt að hún verði á kostnað starfsskilyrða pekkingarfyrirtækja eins og peirra sem listuð eru í töflu 1. Af pví leiðir að skammtímaáherslur á uppbyggingu í anda auðlinda- eða fjárfestingadrifins hagkerfis eru líklegar til að vinna gegn uppbyggingu nýsköpunardrifins hagkerfis, a.m.k. um einhvern tíma.

Prátt fyrir prýsting á stjórnvöld um skammtímaaðgerðir í anda auðlinda- og fjárfestingadrifins hagkerfis vinna pau, ásamt öðrum, að aðgerðum sem miða sérstaklega að pví að styrkja nýsköpunarfyrirtæki. Nú pegar hefur verið lagt fram frumvarp um skattaafslátt til nýsköpunarfyrirtækja og peirra sem fjárfesta í slíkum fyrirtækjum. Auk pess hefur verið sett fjármagn í uppbyggingu frumkvöðlasetra og hugmyndahúsa, bæði af hálfu stjórnvalda og háskóla. Flestar miða pessar aðgerðir að pví að bæta hag sprotafyrirtækja, p.e. nýrra og ungra fyrirtækja sem eru að komast á legg, en hafa minni áhrif á fyrirtæki sem eru lengra komin. Fyrir pau skiptir almennt efnahagsástand meira máli, auk greiðs aðgangs að mörkuðum fyrir vörur og pjónustu, hæfs vinnuafls og fjármagns til vaxtar. Veiking krónunnar styrkir samkeppnisstöðu peirra en gjaldeyrishöft takmarka mjög athafnafrelsi. 
Tafla 1. Listi yfir nokkur nýsköpunarfyrirtæki sem starfa á Íslandi árið 2010 og selja vörur eða pjónustu erlendis

\begin{tabular}{|c|c|c|}
\hline iX Technology & Hafmynd & On waves \\
\hline Actavis & Hampiðjan & ORF \\
\hline AGR & HB tæknipjónusta & Oxymap \\
\hline Amivox & IFOAM & Peocon \\
\hline Andblær & Industria & Primex \\
\hline 3etware & Intelscan & Promens \\
\hline 3láa lónið & Invent Pharma & Remake Electric \\
\hline Zalidris & Íslensk erfðagreining & Responsible Surfing \\
\hline Jaoz & KINE & Saga Medica \\
\hline Zarbon Recycling Int. & LS Retail & Saga Systems \\
\hline ІСР & Mannvit & Stiki \\
\hline Zlara & Marel & Stjörnu-Oddi \\
\hline Jatamarket & Marorka & TellMeTwin \\
\hline Jexta & Martak & Tern Systems \\
\hline Ecoprocess & Menn og mýs & Trackwell \\
\hline JFF 2 Technologies & Mentis Cura & Transmit \\
\hline Incode & Mentor & Tunerific \\
\hline 7jarhitun & Merkurpoint & Unimaze Software \\
\hline Flyware & MindGames & Vaki fiskeldiskerfi \\
\hline JenÍs & Mobilitus & Valka \\
\hline Jogogic & NimbleGen & VDECA \\
\hline Jogyoko & Nox Medical & Ymir Mobile \\
\hline Jreenqloud & Nuevo vehicles & Össur \\
\hline
\end{tabular}

Óvissa er um aðgang að erlendum mörkuðum, t.d. vegna ágreinings við erlend ríki, og tafir við endurreisn fyrirtækja og fjármálakerfis skapa sérstakar aðstæður par sem bankar eru bæði lánveitendur og eigendur fyrirtækja.

Prátt fyrir prönga stöðu í efnahagslífinu standa íslenskum fyrirtækjum til boða ýmis tækifæri til alpjóðlegrar nýsköpunar. Par fara saman tækifæri til mannaflsfrekrar óefnislegrar verðmætasköpunar, lágur launakostnaður vegna lágs gengis króununnar, litlar fjárfestingar í upphafi og minni hindranir vegna fjarlægðar og einangrunar landsins. Pessi tækifæri tengjast gjarnan tölvutækni en eiga pó við rannsóknir og próunarstarf í mörgum greinum. Helsta ógnunin við nýtingu pessara tækifæra er skortur á sérmenntuðu vinnuafli og er pessi skortur pegar farinn að segja til sín hjá mörgum nýsköpunarfyrirtækjum sem vaxa hratt um pessar mundir. Oft er færnin til staðar en hún er ennpá bundin í öðrum greinum.

\section{$5 \quad$ Niðurstöður}

Á níunda áratug síðustu aldar voru Íslendingar komnir í kjörstöðu; höfðu byggt upp velferðarkerfi að norrænni fyrirmynd, réðu yfir miðunum umhverfis landið innan 200 mílna og höfðu aflað fjármuna til að kaupa öflug veiðitæki. Stóraukinn afli og vaxandi verkfræðileg pekking jók í senn afköst og vörugæði í sjávarútvegi en vendipunkturinn varð pó pegar hægt var að umbreyta sjávarútvegstengdri pekkingu og verkfærni í framleiðslu á fiskvinnslutækjum. Pegar síðan kom í ljós að pær lausnir sem próaðar voru innan veiða, 
vinnslu og vörumeðhöndlunar sjávarfangs almennt voru haldgóðar í fjölmörgum öðrum greinum opnuðust möguleikar sem voru mun víðtækari en fyrir var séð. Рað var m.ö.o. ekki aukið verðmæti aflans sem varð afgerandi heldur víðtækari notkunarmöguleikar peirrar framleiðslutækni og pess skipulags sem próað hafði verið fyrir sjávarútveginn. Tækifæri Marels voru ekki bundin við sjávarútveginn heldur náðu pau til matvælaframleiðslu almennt. Á sama hátt var tækni Sæplasts nýtt á fjölbreyttan hátt langt út fyrir matvælavinnslu, t.d. við framleiðslu á íhlutum fyrir bifreiðaframleiðslu, og Bakkavör var um tíma stærsti framleiðandi fyrir smásölukeðjur Bretlands með í kringum 3\% af söluvörum peirra.

Nýsköpun frumkvöðla hafði skapað nýja möguleika til sóknar á erlenda markaði og var í vissum skilningi eðlilegt framhald af pekkingu, færni og alpjóðlegu tengslaneti sem hafði byggst upp um nokkurt skeið. Að vissu marki má skýra umskiptin á grunni kenninga Schumpeters en pó er varasamt að horfa um of til tækninnar eins og honum og flestum fylgjendum hættir til að gera. Skref sem tekin voru í frjálsræðisátt opnuðu erlenda markaði, bæði fyrir vörur og fjármagn. Petta frjálsræði nýttist til vaxtar nýsköpunarfyrirtækja en skapaði líka tækifæri til rentusóknar af áður ópekktri stærðargráðu; stærðargráðu sem tók mið af City í London frekar en raunhagkerfinu á Íslandi.

Hefðbundin atvinnustarfsemi í sjávarútvegi varð óálitlegur fjárfestingarkostur, lítið var um viðskipti á hlutabréfamarkaði og verðgildi fyrirtækjanna vanmetið. Í raun var sjávarútvegsfyrirtækjunum ýtt út af hlutbréfamarkaðnum að Granda frátöldum sem var orðinn eitt af stærstu fyrirtækjum greinarinnar. Á peim örfáu árum sem eiginlegur hlutabréfamarkaður var starfræktur hérlendis breyttist hann í vettvang innantómrar rentusóknar. Í kjölfar hruns fjármálakerfisins komu iðnfyrirtækin, sem upphaflega voru burðarás nútímavæðingarinnar, aftur í ljós. Pau eru enn til staðar, misöflug pó. Auk peirra hefur vaxið upp flóra pekkingarfyrirtækja sem eru mannaflsfrek en purfa ekki miklar efnislegar fjárfestingar til að vaxa og dafna. Vísirinn sem hafði myndast að nýsköpunardrifnu hagkerfi er laskaður en er pó enn til staðar og getur orðið burðarás í atvinnulífinu sé rétt að málum staðið.

Áhersla á uppbyggingu í anda auðlinda- eða fjárfestingadrifins hagkerfis er líkleg til að vinna gegn uppbyggingu nýsköpunardrifins hagkerfis. Nýsköpun er stígbundið ferli par sem sögulegar aðstæður hafa áhrif á uppbyggingu, færni og aðstæður til verðmætasköpunar. Aukinn sjávarafli, meiri landvinnsla á sjávarfangi, meiri orkuvinnsla með núverandi tækni, fleiri ferðamenn og verklegar framkvæmdir sem bæta litlu við núverandi grunngerð og framleiðslukerfi efla að takmörkuðu leyti færni til nýsköpunar, hvorki pekkingarlega eða með bættri grunngerð. Auk pess hefur sagan sýnt að í litlu hagkerfi eins og pví íslenska er áhersla á einstakar atvinnugreinar gjarnan á kostnað annarra. Að pessu sinni er líklegt að hún verði á kostnað starfsskilyrða nýsköpunarfyrirtækja.

Fyrirtæki sem stunda óefnislega, alpjóðlega nýsköpun hafa mikla vaxtarmöguleika við núverandi aðstæður. Pau purfa lítið fjármagn, launakostnaður er samkeppnishæfur og fjarlægðir skipta minna máli. Á móti kemur að gjaldeyrishöft takmarka atvinnufrelsi og pegar er farið að bera á skorti á sérhæfðu starfsfólki. Pessi fyrirtæki eru pjóðhagslega mikilvæg og eru viðbót við íslenskt atvinnulíf. Ólíkt pví sem áður var, pegar nýsköpun var staðbundin og snerist um að innleiða nýjungar erlendis frá, eru pessi fyrirtæki líkleg til að skapa verkefni fyrir grunngeira atvinnulífsins en ekki öfugt. Pess vegna er eðlilegt að atvinnustefna taki mið af pví og dragi úr vægi stuðnings við grunngeira en leggi áherslu á að efla nýsköpunarhæfni. 
Pó svo að fall bankakerfisins hafi á vissan hátt létt farginu af pekkingarfyrirtækjunum og veiking krónunnar bætt samkeppnisstöðu peirra er hætta á að stjórnvaldsaðgerðir, eða skortur á aðgerðum, skapi ójafnvægi og óvissu sem grefur undan fyrirtækjunum. Sem dæmi má nefna óleystar milliríkjadeilur og óvissu um samspil ríkis og einkaaðila. Einnig er mikilvægt að leiðrétta pá hagrænu hvata sem hvöttu til rentusóknar og útbúa stofnanaumgjörð og eftirlitskerfi sem takmarkar pá áhættu sem almenningur ber af einkageiranum. Pannig skapast forsendur fyrir pví að nýsköpun verði hreyfiafl breytinga án pess að áhættan verði meiri en samfélagið getur borið.

Раð dylst engum að samfélagið í heild sinni er verulega laskað eftir pað sem á undan er gengið. Margt hefur tekist vel til skamms tíma en pó hefur dregist að afgreiða mikilvæg mál og langtíma stefnumótun er ennpá að nokkru óljós. Gjörbreytt starfsskilyrði og leiðrétting í kjölfar bankahrunsins hafa skapað ný tækifæri fyrir árvökul augu íslenskra frumkvöðla og pað er mikilvægt að peim sé ekki fórnað fyrir skammtímalausnir sem byggja á frekari nýtingu fullnýttra auðlinda, hversu freistandi sem pað kann að vera.

\section{Heimildir}

Baumol, W. J. (1990). Entrepreneurship: Productive, unproductive, and destructive. Journal of Political Economy, 98(5), 893-921.

Dahmén, E. (2004). Próunarsamfellur í atvinnuvegahagfræði. Í Örn D. Jónsson (ritstj.), Nýsköpun. Staður - stund (bls. 23-40). Reykjavík: Viðskipta- og hagfræðideild Háskóla Íslands.

Erla Kristinsdóttir (2009). Kauphöll og sjávarútvegur. Eiga pau samleið? Óbirt MS ritgerð í viðskiptafræði: Háskóli Íslands, Viðskiptafræðideild.

Guðmundur Jónsson (2002). Hagpróun og hagvöxtur á Íslandi 1914-1960. Í Jónas H. Haralz (ritstj.), Frá kreppu til viðreisnar. Pættir um hagstjórn á Íslandi á árunum 1930 til 1960 (bls. 939). Reykjavík: Hið íslenska bókmenntafélag.

Kirzner, I. M. (1973). Competition and Entrepreneurship. Chicago: The University of Chicago Press.

Kirzner, I. M. (1997). Entrepreneurial discovery and the competitive market process: An Austrian Approach. Journal of Economic Literature, 35(1), 60-85.

Páll Hreinsson, Sigríður Benediksdóttir og Tryggvi Gunnarsson (ritstj.) (2010). Aðdragandi og orsakir falls íslensku bankanna 2008 og tengdir atburđir. Reykjavík: Rannsóknarnefnd Alpingis.

Rannsóknarráð Íslands (1996). Skýrsla Rannsóknarráđs Íslands til menntamálaráðherra 1996. Reykjavík: Rannsóknarráð Íslands.

Schumpeter, J. A. (1934). The Theory of Economic Development. Cambridge, MA: Harvard University Press.

Schumpeter, J. A. (1976/1942). Capitalism, Socialism and Democracy. London: Routledge.

Verslunarráð Íslands (2004). Einkaframkvæmd - Samkeppni á nýjum sviðum. Reykjavík: Verslurnarráð Íslands.

Örn D. Jónsson (2000). Regional Aspect of the Icelandic Innovation System. Óbirt doktorsritgerð. Roskilde Universitet.

Örn D. Jónsson og Rögnvaldur J. Sæmundsson (2006). Isolation as a source of entrepreneurial opportunities: Overcoming the limitations of isolated micro-states. Í 
74 Tímarit um viðskipti og efnahagsmál

Galbraith, C. og Stiles, C. (ritstj.) Developmental Entrepreneurship: Adversity, Risk, and Isolation. Oxford: Elsevier. 